Article

\title{
Incorporation of Low Molecular Weight Chitosan in a Low-Fat Beef Burger: Assessment of Technological Quality and Oxidative Stability
}

\author{
Pourya Izadi Amoli ${ }^{1}$, Milad Hadidi ${ }^{2, *(D)}$, Zahra Hasiri ${ }^{3}$, Arman Rouhafza ${ }^{3}$, Aniseh Zarei Jelyani ${ }^{4}$, \\ Zahra Hadian ${ }^{5}$ D, Amin Mousavi Khaneghah ${ }^{6, *(D)}$ and José M. Lorenzo ${ }^{7,8, *(\mathbb{D})}$
}

\section{check for}

updates

Citation: Amoli, P.I.; Hadidi, M.; Hasiri, Z.; Rouhafza, A.; Jelyani, A.Z.; Hadian, Z.; Khaneghah, A.M.; Lorenzo, J.M. Incorporation of Low Molecular Weight Chitosan in a Low-Fat Beef Burger: Assessment of Technological Quality and Oxidative Stability. Foods 2021, 10, 1959. https://doi.org/10.3390/foods10081959

Academic Editor: Diana Ansorena Artieda

Received: 16 July 2021

Accepted: 17 August 2021

Published: 23 August 2021

Publisher's Note: MDPI stays neutral with regard to jurisdictional claims in published maps and institutional affiliations.

Copyright: (C) 2021 by the authors Licensee MDPI, Basel, Switzerland. This article is an open access article distributed under the terms and conditions of the Creative Commons Attribution (CC BY) license (https:// creativecommons.org/licenses/by/ $4.0 /)$
1 Department of Food Science and Technology, Science and Research Branch, Islamic Azad University, Tehran 14778-93855, Iran; Izadi.Amoli@live.com

2 Department of Organic Chemistry, Faculty of Chemical Sciences and Technologies, University of Castilla-La Mancha, 13071 Ciudad Real, Spain

3 College of Veterinary Medicine, Islamic Azad University of Shahrekord, Shahrekord 88137-33395, Iran; zahrahasiri7@gmail.com (Z.H.); A.rouhafza@gmail.com (A.R.)

4 Food Control Laboratory, Department of Food and Drug, Shiraz University of Medical Science, Shiraz 71348-14336, Iran; aniseh.zarei@gmail.com

5 Department of Food Technology Research, National Nutrition and Food Technology Research Institute, Faculty of Nutrition Sciences and Food Technology, Shahid Beheshti University of Medical Sciences, Tehran 19816-19573, Iran; z_hadian@sbmu.ac.ir

6 Department of Food Science and Nutrition, Faculty of Food Engineering, University of Campinas (UNICAMP), Campinas, São Paulo 13083-852, Brazil

7 Centro Tecnológico de la Carne de Galicia, Rúa Galicia No 4, Parque Tecnológico de Galicia, San Cibrao das Viñas, 32900 Ourense, Spain

8 Área de Tecnologia de los Alimentos, Facultad de Ciencias de Ourense, Universidad de Vigo, 32004 Ourense, Spain

* Correspondence: milad.hadidi@gmail.com (M.H.); mousavi@unicamp.br or mousavi.amin@gmail.com (A.M.K.); jmlorenzo@ceteca.net (J.M.L.)

Abstract: In the present work, incorporating low molecular weight chitosan (LMWCH) $(0,0.5,1$, and $2 \%$ ) as a fat replacer into low-fat beef burgers and technological, textural, and oxidative stability were investigated. The weight loss and shrinkage of samples decreased with the increase of LMWCH concentration. In contrast, the water-holding capacity and color of burgers were enhanced by the addition of LMWCH. The instrumental TPA results indicated an increase in the LMWCH levels, significantly increasing the hardness, springiness, and gumminess but decreasing the cohesiveness of low-fat beef burgers. The TBARS and peroxide values and free fatty acid content in the burgers supplemented with $\mathrm{LMWCH}$ increase slower than the control sample during refrigerated storage.

Keywords: low-fat burger; chitosan; fat replacer; lipid oxidation; quality

\section{Introduction}

Meat products such as burgers may be excellent sources of protein and essential nutrients in different age groups. However, several scientific pieces of evidence have shown the connection between animal fat intake and increased risk of significant health problems, including obesity, colon cancer, and cardiovascular diseases [1]. Hence, meat consumers look for healthier meat substitutes as a means to maintain good health. This new approach gives the meat industry an excellent opportunity to develop new products such as functional foods [2]. The use of fat replacer is the most efficient way to achieve low-fat products; however, the technical quality and color of meat products may be affected by the reduction of fat $[3,4]$. For this reason, many water retention hydrocolloids have been studied to boost gels' development, including alginate, chitosan, gums, cellulose, and pectin $[5,6]$. 
Nowadays, demand for non-artificial food additives has increased, so natural ingredients are preferred. Chitosan is a cationic amino polysaccharide obtained by alkaline deacetylation of chitin. The application of chitosan in food and pharmaceutical products is mainly seen due to its unique bioactivities and functional properties [7]. Besides, its antimicrobial potential has other interesting characteristics, including antioxidant activity, lipid binding, water-holding capacities, and emulsifying properties [8,9]. Chitosan has illustrated considerable potential to enhance meat products' technological and nutritional quality $[10,11]$. However, its utilization in the food system is limited due to its high molecular weight (50-800 $\mathrm{kDa}$ ) and low water solubility. The molecular weight of this polysaccharide affects its biological activity [12].

Nevertheless, few studies have reported the use of chitosan as a fat replacer in meat products. This study investigates the effect of adding different concentrations of LMWCH on the technological and textural properties of low-fat beef burgers. Moreover, the oxidative stability of low-fat beef burgers during refrigerated storage was evaluated.

\section{Materials and Methods}

\subsection{Materials}

Ten prime cuts of foreshank cuts from heifer carcasses of mean age 16 months were obtained in a butcher in Gorgan, Iran, at 2 days post mortem and kept in a refrigerator $\left(4^{\circ} \mathrm{C}\right)$. Low molecular weight chitosan with a 50-190 kDa molecular weight and a deacetylation degree of $75-85 \%$ was provided from Sigma-Aldrich Co. (Louis, MO, USA). Spices and other additives were purchased from the local market. All the other chemicals and reagents were of analytical grade and were obtained from Sigma-Aldrich Co. (Louis, MO, USA) or Merck Chemicals Co. (Darmstadt, Germany).

\subsection{Preparation of Low-Fat Beef Burgers}

The low-fat beef burgers were produced to the following formulation: fresh beef $(82 \%)$, beef back fat $(4 \%)$, onion powder $(4 \%)$, texturized soybean protein $(2.75 \%)$, gluten $(1 \%)$, burger seasoning $(1 \%)$, betanin dye (beetroot red, E162) $(0.025 \%)$, salt $(1.5 \%)$, and water $(4 \%)$. Firstly, the beef and fat were sliced and minced in an electronic mincer with a $10 \mathrm{~mm}$ hole plate (MG510, Kenwood, China) to make the burgers. Then, cold water and salt were added to the meat mix. Next, burger seasoning, texturized soybean protein, and the LMWCH in four levels $(0,0.5,1$, and $2 \% w / w)$ were added(Table 1$)$ and mixed for 2 min using a blender (FP6031, Moulinex, France). The uniform dough was packed in plastic bags and transported in a freezer at $-18{ }^{\circ} \mathrm{C}$. Afterward $12 \mathrm{~h}$, the dough was sliced with a hamburger slicer (CM-SL30, Changmag, Taiwan) and placed in a freezer at $75 \mathrm{~g}$ weight and an average diameter of $10 \mathrm{~cm}$ in low-density polyethylene bags. The burgers were cooked in a preheated electrical grill (SBG 106BK, Sencor, Czech Republic) at $180{ }^{\circ} \mathrm{C}$ for a total of $8 \mathrm{~min}$ ( $4 \mathrm{~min}$ for each side) and then heated up until the internal temperature of the geometrical center of each burger was $75^{\circ} \mathrm{C}$. The formulation of the control sample was similar to all treatments, except $10 \%$ fat was added in beef burger formulation without the addition of LMWCH (Table 1). The elaboration of burgers was replicated using the same ingredients and protocols on three different days.

Table 1. Formulations of five different beef burgers.

\begin{tabular}{ccc}
\hline Sample & LMWCH (\%) & Fat (\%) \\
\hline Control & 0 & 10 \\
0 & 0 & 4 \\
0.5 & 0.5 & 4 \\
1 & 1 & 4 \\
2 & 2 & 4 \\
\hline
\end{tabular}




\subsection{Product Quality Analysis}

\subsubsection{Cooking Loss}

Cooking loss percentage was measured according to the method of Akwetey and Knipe [13]. A total of $20 \mathrm{~g}$ of beef burger samples was shaped to form a circular loop. The weight of burgers was determined before and after being cooked in an electric grill.

\subsubsection{Water-Holding Capacity (WHC)}

The WHC of samples was determined as described by Yousefi et al. [14]. To determine the WHC, four layers of Whatman filter papers were put in $2 \mathrm{~mL}$ vials. The filter papers and vials were weighted before centrifugation. Then, burger samples $(0.5 \mathrm{~g})$ were placed into the vials. Vials were centrifuged at $14,000 \times g$ for $10 \mathrm{~min}$. Then, the burger pieces were pulled out from the vials, and the weight of vials and filter papers was determined.

WHC $(\%)=($ weight after centrifugation - weight before centrifugation $) /($ weight after centrifugation $) \times 100$

\subsubsection{Shrinkage}

The beef burger shrinkage was measured according to the method of Piñero et al. [15]. A difference between the uncooked burger diameter and cooked burger diameter was regarded as the percentage of shrinkage and calculated as follows:

Shrinkage $(\%)=($ diameter of uncooked burger - diameter of cooked burger $) /($ diameter of uncooked burger $) \times 100$

\subsubsection{Color Analysis}

The surface color of the beef burger was determined with a Konica Minolta colorimeter using a three-dimensional CIE system with a $10^{\circ}$ observer angle, $8 \mathrm{~mm}$ aperture, and illuminant A, and calibrated against a white tile (CR 330, Tokyo, Japan) recording $\mathrm{L}^{*}$ (lightness), $\mathrm{a}^{*}$ (redness), and $\mathrm{b}^{*}$ (yellowness) values.

\subsubsection{Texture Profile Analysis (TPA)}

TPA of burgers was measured in an XT-PLUS Texture Analyzer (SMS, Surrey, UK). One portion of the sample $(1 \times 2 \mathrm{~cm}$ diameter $)$ was sliced from the center of the cooked burger, underwent a double compression cycle test of $50 \%$ compression by the cylindrical probe of $3.6 \mathrm{~cm}$ diameter and a cross-head speed of $2 \mathrm{~mm} / \mathrm{s}$. Five textural factors, namely, hardness (force $(\mathrm{N})$ required for the first compression), springiness (distance of sample recovery after the first compression), cohesiveness (ratio of the active work completed under the second forced is placement curve to that completed under the first compression curve (dimensionless)), and chewiness (cohesiveness $\times$ springiness $\times$ hardness $(\mathrm{cm} / \mathrm{N})$ ) were computed [5].

\subsubsection{Oxidative Stability}

Lipid oxidation and $\mathrm{pH}$ of raw burger samples were evaluated after zero, 2, 4, 6, 8, and 10 days of storage under refrigeration $\left(4{ }^{\circ} \mathrm{C}\right)$. Thiobarbituric acid reactive substances (TBARS) value was determined using the extraction method defined by Hautrive et al. [5]. Free fatty acid (FFA) and peroxide value (PV) of the burger samples were measured using a titration method according to AOAC Official Methods [16].

\subsection{7. $\mathrm{pH}$ Values}

The $\mathrm{pH}$ of raw samples was determined using a portable Crison $507 \mathrm{pH}$-meter (Alella, Barcelona, Spain) with incorporation calibrated electrode specific for meat products.

\subsubsection{Statistical Analysis}

All experimental data were expressed as means \pm standard deviations (five treatments with three replications were used) after passing the analysis of variance (ANOVA) and 
Duncan's multiple range tests using SPSS statistics software (ver. 22.0). $p<0.05$ was accepted to be statistically significant.

\section{Results}

\subsection{Technological Properties}

Table 2 illustrates the effect of adding LMWCH at different levels on technological properties (cooking weight loss, WHC, shrinkage, and color) of low-fat beef burger samples. The weight loss and shrinkage of samples significantly decreased with the increase of LMWCH concentration. In contrast, the WHC of burgers was significantly increased by the addition of LMWCH. Chitosan demonstrates barrier capabilities to prevent water removal during the cooking process by making water molecular hydrogen bonds that make them more effective to avoid weight loss in the final product [10]. The proportion of non-meat components in the ground meat products formulations such as beef hamburgers can change the color of products. When the level of added chitosan was increased, the samples were observed to have higher lightness $\left(\mathrm{L}^{*}\right)$, which is related to the moisture-retaining ability of chitosan, whereas Jo et al. [17] observed an increasing trend in $L^{*}$ values of pork sausages containing chitosan. Redness $\left(\mathrm{a}^{*}\right)$ significantly improved with rising the concentration of LMWCH in low-fat beef burgers; this would be due to the effect of this chitosan on the burger's texture [18]. A similar trend was reported by Sayas-Barberá et al. [19], who studied the influence of adding chitosan at different molecular weights in pork burgers. Additionally, the yellowness and redness were increased by the increment of chitosan. Jo et al. [17] confirm the yellowness results as they observed that the augmentation of chitosan increased the $b^{*}$ value of meat products, indicating that the chitosan's natural color influenced the surface color of the final products.

Table 2. Technological properties of the control sample and low-fat beef burger supplemented with different concentrations of LMWCH $(\%)$.

\begin{tabular}{|c|c|c|c|c|c|c|}
\hline \multirow{2}{*}{ Sample } & \multirow{2}{*}{ Cooking Loss (\%) } & \multirow{2}{*}{ WHC (\%) } & \multirow{2}{*}{ Shrinkage (\%) } & \multicolumn{3}{|c|}{ Color } \\
\hline & & & & $\mathbf{L}^{*}$ & $a^{*}$ & $\mathbf{b}^{*}$ \\
\hline Control & $24.9 \pm 2.9^{b}$ & $33.6 \pm 3.4^{\mathrm{cd}}$ & $14.4 \pm 0.8^{\mathrm{a}}$ & $35.4 \pm 3.5^{c}$ & $4.8 \pm 0.5^{c}$ & $11.1 \pm 0.8^{\mathrm{d}}$ \\
\hline 0 & $27.6 \pm 1.5^{\mathrm{a}}$ & $32.9 \pm 1.3^{\mathrm{d}}$ & $13.5 \pm 1.2^{b}$ & $33.1 \pm 4.2^{\mathrm{d}}$ & $4.9 \pm 0.3^{c}$ & $12.6 \pm 0.5^{\mathrm{c}}$ \\
\hline 0.5 & $21.2 \pm 1.8^{\mathrm{c}}$ & $34.2 \pm 2.7^{c}$ & $13.1 \pm 0.9^{b}$ & $35.5 \pm 1.6^{c}$ & $5.6 \pm 0.7^{b c}$ & $13.9 \pm 0.7^{b}$ \\
\hline 1 & $18.3 \pm 2.3^{d}$ & $37.5 \pm 4.1^{\mathrm{b}}$ & $10.7 \pm 1.5^{c}$ & $36.6 \pm 3.8^{b}$ & $6.1 \pm 0.3^{b}$ & $14.5 \pm 1.1^{\mathrm{ab}}$ \\
\hline 2 & $17.1 \pm 2.5^{\mathrm{e}}$ & $40.1 \pm 3.5^{\mathrm{a}}$ & $9.8 \pm 0.6^{c}$ & $37.9 \pm 1.5^{\mathrm{a}}$ & $7.6 \pm 0.4^{\mathrm{a}}$ & $15.2 \pm 0.4^{\mathrm{a}}$ \\
\hline
\end{tabular}

Means \pm SD in the same column with different superscripts are significantly different $(p>0.05)$. $\mathrm{L}^{*}$ (lightness), $\mathrm{a}^{*}$ (redness), and $\mathrm{b}^{*}$ (yellowness) values.

\subsection{Textural Properties}

The impact of the increment of LMWCH on the texture profile of the low-fat beef burgers is illustrated in Table 3. The hardness of low-fat beef burgers as a maximum power needed to compress the samples increased significantly from 124 to $147.9 \mathrm{~N}$ when the LMWCH concentration increased from 0 to $2 \%(p<0.05)$. This increase might be ascribed to the higher fat retention and lower moisture retention after the cooking process by the burgers containing $\mathrm{LMWCH}$ [5]. The instrumental TPA results indicated that the increment of LMWCH negatively affected the cohesiveness value $(p<0.05)$. Majzoobi et al. [20] observed that the different concentrations of carrageenan and konjac mannan increased hardness while reducing the meat-free sausages' springiness and cohesiveness. Various authors have observed that the increment of non-meat components reduces the springiness and cohesiveness of meat products [5]. The addition of LMWCH to low-fat beef burgers caused an increase in springiness and gumminess. 
Table 3. Textural characterizations of the control sample and low-fat beef burger supplemented with different concentrations of LMWCH (\%).

\begin{tabular}{cccccc}
\hline Sample & Hardness (N) & Cohesiveness & Springiness & Gumminess & $\begin{array}{c}\text { Chewiness } \\
(\mathbf{c m} / \mathbf{N})\end{array}$ \\
\hline Control & $124.0 \pm 6.8^{\mathrm{e}}$ & $0.59 \pm 0.05^{\mathrm{a}}$ & $5.95 \pm 0.2^{\mathrm{d}}$ & $59.3 \pm 3.4^{\mathrm{d}}$ & $450.5 \pm 24.9^{\mathrm{b}}$ \\
0 & $136.3 \pm 5.4^{\mathrm{d}}$ & $0.51 \pm 0.03^{\mathrm{b}}$ & $6.26 \pm 0.4^{\mathrm{cd}}$ & $63.7 \pm 1.9^{\mathrm{c}}$ & $463.2 \pm 10.6^{\mathrm{a}}$ \\
0.5 & $139.5 \pm 6.0^{\mathrm{c}}$ & $0.45 \pm 0.01^{\mathrm{c}}$ & $6.49 \pm 0.6^{\mathrm{c}}$ & $66.8 \pm 4.5^{\mathrm{b}}$ & $463.8 \pm 28.2^{\mathrm{a}}$ \\
1 & $143.4 \pm 4.5^{\mathrm{b}}$ & $0.44 \pm 0.03^{\mathrm{c}}$ & $6.95 \pm 0.4^{\mathrm{b}}$ & $67.1 \pm 2.2^{\mathrm{ab}}$ & $461.3 \pm 17.5^{\mathrm{a}}$ \\
2 & $147.9 \pm 3.7^{\mathrm{a}}$ & $0.40 \pm 0.01^{\mathrm{d}}$ & $7.74 \pm 0.9^{\mathrm{a}}$ & $68.2 \pm 1.7^{\mathrm{a}}$ & $462.1 \pm 21.8^{\mathrm{a}}$ \\
\hline
\end{tabular}

Means \pm SD in the same column with different superscripts are significantly different $(p>0.05)$.

Furthermore, the addition of chitosan had no significant effect on the chewiness of samples $(p>0.05)$. Estévez et al. [21] represented that the gumminess parameter relies on the hardness value, which justifies the similar trend showed by these parameters. Gumminess is the required power to disjoint a semi-solid state of the sample until swallowing.

\subsection{Lipid Oxidation and $\mathrm{pH}$ during Refrigerator Storage}

The $\mathrm{pH}$ values of samples varied from 5.6 to 6.13 during storage (Figure 1a). The low-fat beef burger showed higher $\mathrm{pH}$ than the control sample over the entire storage period. This phenomenon could be ascribed to the high $\mathrm{pH}$ of the chitosan used (8.75). Chitosan's high $\mathrm{pH}$ can be due to its extraction method from crustacean shells, in which the chitin, a chitosan precursor, is treated with concentrated $\mathrm{NaOH}$ solution $(40-50 \%)$ so that the reaction of deacetylation occurs, originating the chitosan [22]. Meat $\mathrm{pH}$ values near the myofibrillary protein isoelectric point $(\sim 5.4)$ reduce the WHC of myosin protein because of maximum protein-protein interaction and minimum protein-water interaction, leaking water from the meat product and negatively affecting meat quality [23-25]. These results agree with those reported by Turhan et al. [26] and Hautrive et al. [5], who reported higher $\mathrm{pH}$ values in low-fat burgers supplemented with chitosan and other fiber.

It is well known that lipid oxidation reduces meat products' quality and sensory properties because it leads to color decrement and extension of off-flavors and off-odors $[27,28]$. The TBARS value of all low-fat beef burgers and control samples increased during 10 days of storage at $4{ }^{\circ} \mathrm{C}$ in the refrigerator. However, the TBARS production was significantly $(p<0.05)$ inhibited in low-fat beef burgers supplemented with chitosan, compared with the control burger over a 10-day storage period (Figure 1b). According to Dominguez et al. [29], fat contents and fatty acid composition are the key factors in the lipid oxidation of meat because fatty acids are the oxidation processes' substrate. In this regard, the difference in TBARS values between control and $\%$ low-fat burgers (1.28 vs. $1.15 \mathrm{mg} \mathrm{MDA} / \mathrm{kg}$ ) could be due to the fat content since the control burgers were elaborated with $10 \%$ fat. This result agrees with data reported by other authors [30-34] in different meat products who observe higher lipid oxidation in meat products with high fat content. Regarding the LMWCH effect, the burger manufactured with $2 \%$ of LMWCH presented the lowest TBARS values on the last day of storage $(1.1,0.97$, and $0.92 \mathrm{mg} \mathrm{MDA} / \mathrm{kg}$, for $0.5,1$, and $2 \% \mathrm{LMWCH}$, respectively). In addition, the low-fat beef burger formulated with $\operatorname{LMWCH}(0.5,1$, and $2 \%$ ) at all storage days illustrated values lower than the threshold for off-flavor perception by sensory evaluation $(1.0 \mathrm{mg} \mathrm{MDA} / \mathrm{kg})$ [35]. The result of TBARS analysis confirms the potent effect of the LMWCH in inhibiting lipid oxidation in a low-fat beef burger, such as the previously described antioxidant activity of LMWCH [5,36]. 


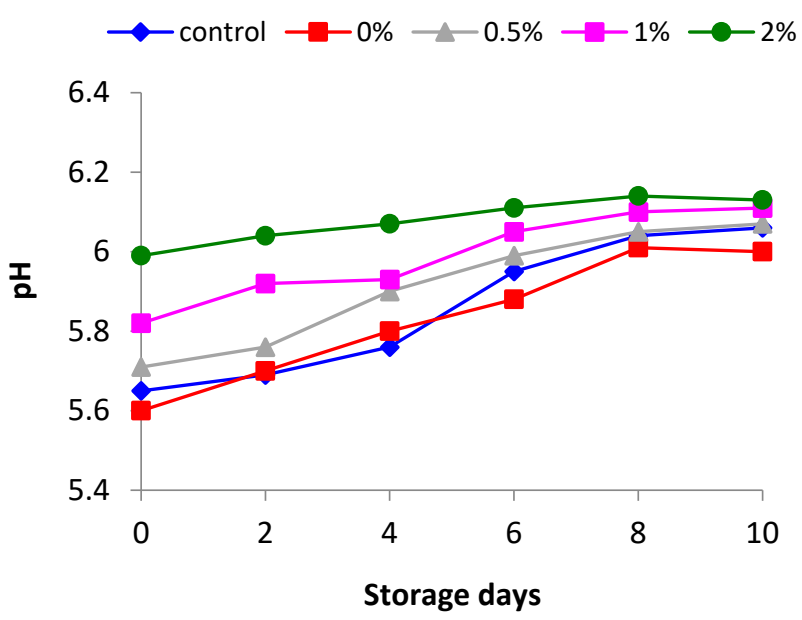

(a)

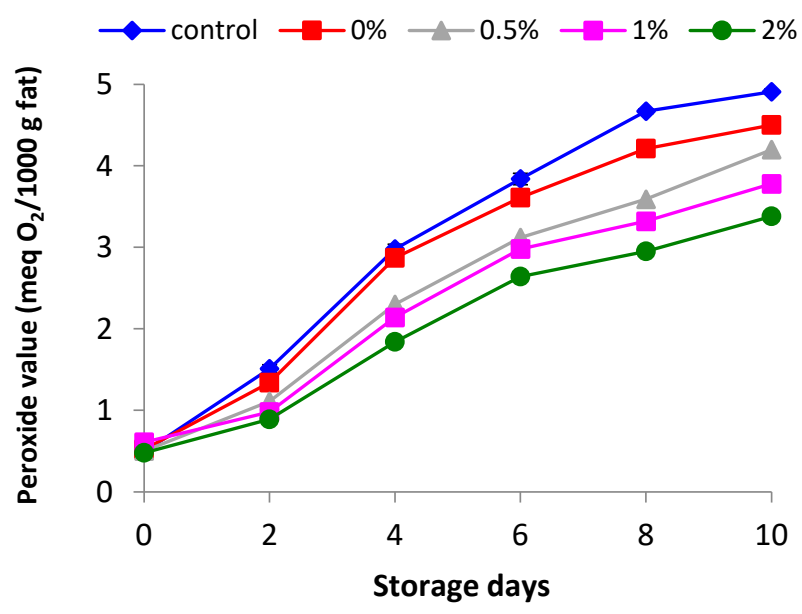

(c)

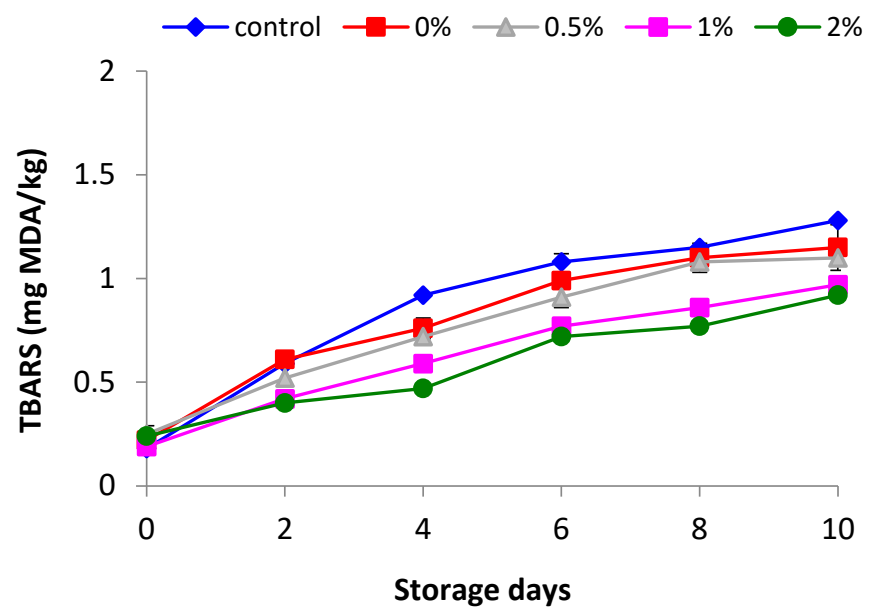

(b)

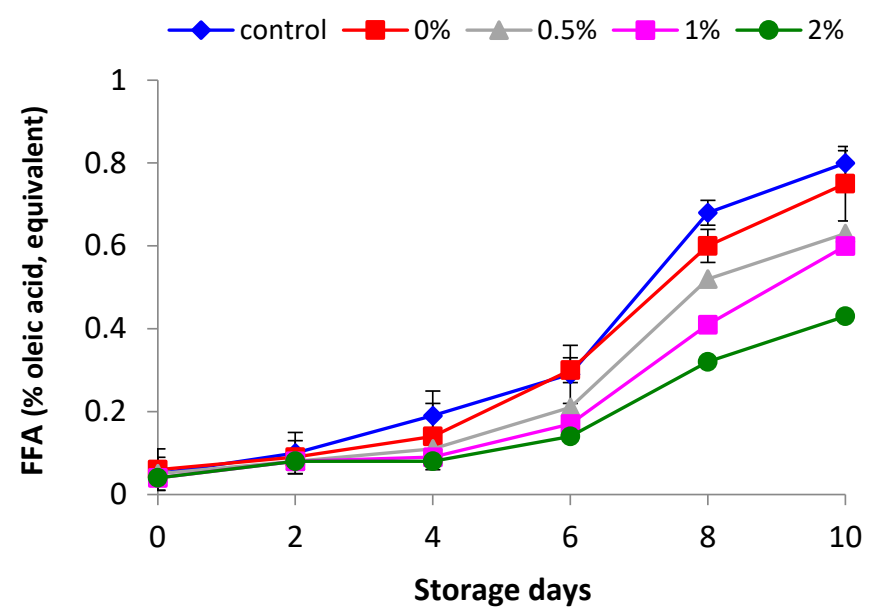

(d)

Figure 1. Effect of different concentrations of LMWCH (\%) on $\mathrm{pH}(\mathbf{a})$, TBARS (b), peroxide (c), and free fatty acid (d) values in low-fat beef burger and control sample during 10 days of storage in the refrigerator $\left(4^{\circ} \mathrm{C}\right)$.

These results agree with those reported by Turhan et al. [28] and Hautrive et al. [5], who reported higher $\mathrm{pH}$ values in low-fat burgers supplemented with chitosan and other fiber. The TBARS value of all low-fat beef burgers and control samples increased during 10 days of storage at $4{ }^{\circ} \mathrm{C}$ in the refrigerator. However, the TBARS production was significantly $(p<0.05)$ inhibited in low-fat beef burgers supplemented with chitosan, compared with the control burger over a 10-day storage period (Figure 1b). This difference in TBARS values between control and $0 \%$ low-fat burgers could be due to the fat content since the control burgers were elaborated with $10 \%$ fat. On the other hand, the low-fat beef burger formulated with $\operatorname{LMWCH}(0.5,1$, and $2 \%)$ at all storage days indicated values lower than the threshold for off-flavor perception by sensory evaluation (1.0 mg MDA/ $\mathrm{kg})$ [35]. The result of TBARS analysis confirms the potent effect of the LMWCH in inhibiting lipid oxidation in a low-fat beef burger, such as the previously described antioxidant activity of LMWCH $[5,36]$. The results indicated an increasing trend in peroxide values for all the samples during storage, but the values were much under the maximum acceptable limit (10-20 meq $/ \mathrm{kg}$ ) for peroxide value in meat products (Figure 1c).

Further, this study indicated that the control sample's peroxide value was significantly higher than the low-fat beef burger supplemented with chitosan at all storage days $(p<0.05)$. The replacement of fat with chitosan decreased the FFA value of beef burgers. 
The lowest FFA value was found in the low-fat beef burgers formulated with $2 \% \mathrm{LMWCH}$ during storage (Figure 1d). These results agree with Jeyakumari et al. [37], who observed that the antioxidant activity of chitosan helps avoid the lipid oxidation in the Pangasius surimi supplemented by chitosan.

\section{Conclusions}

Technological, textural, and lipid oxidation of beef burgers were affected by the increment of $\mathrm{LMWCH}$. The results indicated that the incorporation of LMWCH in low-fat beef burger formulations significantly enhanced the technological quality of the burgers due to their high WHC. The lipid deterioration was inhibited in a low-fat beef burger formulated with LMWCH compared with the control burger over a 10-day storage period. LMWCH successfully reduced the negative effects associated with lowering the fat content of beef burgers, which illustrated that LMWCH has more potential in acting as a proper fat replacer.

Author Contributions: Conceptualization, P.I.A. and M.H.; formal analysis, P.I.A., Z.H. (Zahra Hasiri), A.Z.J. and A.R.; writing-original draft preparation, M.H. and A.M.K. and Z.H. (Zahra Hadian); writing - review and editing, M.H. and J.M.L. All authors have read and agreed to the published version of the manuscript.

Funding: This research received no specific grant.

Data Availability Statement: The data presented in this study are available on request from the corresponding author.

Conflicts of Interest: The authors declare no conflict of interest related to the content of this manuscript.

\section{References}

1. Mehta, N.; Ahlawat, S.S.; Sharma, D.P.; Dabur, R.S. Novel trends in the development of dietary fiber-rich meat products- a critical review. J. Food Sci. Technol. 2015, 52, 633-647. [CrossRef] [PubMed]

2. Valenzuela-Melendres, M.; Camou, J.; Olivera, N.T.; Almora, E.Á.; Mendoza, D.G.; Reyes, L.A.; Ríos, H.G. Response surface methodology for predicting quality characteristics of beef patties added with flaxseed and tomato paste. Meat Sci. 2014, 97, 54-61. [CrossRef] [PubMed]

3. Das, A.K.; Nanda, P.K.; Madane, P.; Biswas, S.; Das, A.; Zhang, W.; Lorenzo, J.M. A comprehensive review on antioxidant dietary fibre enriched meat-based functional foods. Trends Food Sci. Technol. 2020, 99, 323-336. [CrossRef]

4. Gómez, M.; Lorenzo, J.M. Effect of fat level on physicochemical, volatile compounds and sensory characteristics of dry-ripened "chorizo" from Celta pig breed. Meat Sci. 2013, 95, 658-666. [CrossRef]

5. Hautrive, T.P.; Piccolo, J.; Rodrigues, Â.S.; Campagnol, P.C.B.; Kubota, E.H. Effect of fat replacement by chitosan and golden flaxseed flour (wholemeal and defatted) on the quality of hamburgers. LWT Food Sci. Technol. 2019, 102, 403-410. [CrossRef]

6. López-Pedrouso, M.; Lorenzo, J.M.; Gullón, B.; Campagnol, P.C.B.; Franco, D. Novel strategy for developing healthy meat products replacing saturated fat with oleogels. Curr. Opin. Food Sci. 2021, 40, 40-45. [CrossRef]

7. Hesami, G.; Darvishi, S.; Zarei, M.; Hadidi, M. Fabrication of chitosan nanoparticles incorporated with Pistacia atlantica subsp. kurdica hulls' essential oil as a potential antifungal preservative against strawberry grey mould. Int. J. Food Sci. Technol. 2021. [CrossRef]

8. Hadidi, M.; Motamedzadegan, A.; Jelyani, A.Z.; Khashadeh, S. Nanoencapsulation of hyssop essential oil in chitosan-pea protein isolate nano-complex. LWT Food Sci Technol. 2021, 144, 111254. [CrossRef]

9. Wang, J.; Shi, D.; Bai, Y.; Ouyang, B.; Liu, Y. Effects of chitosan treatment on the texture parameters of okra fruit (Abelmoschus esculentus L. Moench). Qual. Assur. Saf. Crop. Foods 2020, 12, 66-75. [CrossRef]

10. do Amaral, D.S.; Cardelle-Cobas, A.; do Nascimento, B.M.S.; Monteiro, M.J.; Madruga, M.S.; Pintado, M.M.E. Development of a low fat fresh pork sausage based on chitosan with health claims: Impact on the quality, functionality and shelf-life. Food Funct. 2015, 6, 2768-2778. [CrossRef]

11. Ozaki, M.M.; Munekata, P.E.S.; de Lopes, A.S.; do da Nascimento, M.S.; Pateiro, M.; Lorenzo, J.M.; Pollonio, M.A.R. Using chitosan and radish powder to improve stability of fermented cooked sausages. Meat Sci. 2020, 167, 108165. [CrossRef]

12. Kim, K.W.; Thomas, R.L. Antioxidative activity of chitosans with varying molecular weights. Food Chem. 2007, 101, 308-313. [CrossRef]

13. Akwetey, W.Y.; Knipe, C.L. Sensory attributes and texture profile of beef burgers with gari. Meat Sci. 2012, 92, 745-748. [CrossRef] [PubMed]

14. Yousefi, N.; Zeynali, F.; Alizadeh, M. Optimization of low-fat meat hamburger formulation containing quince seed gum using response surface methodology. J. Food Sci. Technol. 2018, 55, 598-604. [CrossRef] 
15. Piñero, M.P.; Parra, K.; Huerta-Leidenz, N.; Arenas de Moreno, L.; Ferrer, M.; Araujo, S.; Barboza, Y. Effect of oat's soluble fibre ( $\beta$-glucan) as a fat replacer on physical, chemical, microbiological and sensory properties of low-fat beef patties. Meat Sci. 2008, 80, 675-680. [CrossRef] [PubMed]

16. AOAC Official Methods of Analysis of AOAC International. AOAC 2005. Available online: https://www.aoac.org/officialmethods-of-analysis-18th-edition-2005/ (accessed on 16 July 2021).

17. Jo, C.; Lee, J.W.; Lee, K.H.; Byun, M.W. Quality properties of pork sausage prepared with water-soluble chitosan oligomer. Meat Sci. 2001, 59, 369-375. [CrossRef]

18. Georgantelis, D.; Ambrosiadis, I.; Katikou, P.; Blekas, G.; Georgakis, S.A. Effect of rosemary extract, chitosan and $\alpha$-tocopherol on microbiological parameters and lipid oxidation of fresh pork sausages stored at $4{ }^{\circ} \mathrm{C}$. Meat Sci. 2007, 76, 172-181. [CrossRef] [PubMed]

19. Sayas-Barberá, E.; Quesada, J.; Sánchez-Zapata, E.; Viuda-Martos, M.; Fernández-López, F.; Pérez-Alvarez, J.A.; Sendra, E. Effect of the molecular weight and concentration of chitosan in pork model burgers. Meat Sci. 2011, 88, 740-749. [CrossRef] [PubMed]

20. Majzoobi, M.; Talebanfar, S.; Eskandari, M.H.; Farahnaky, A. Improving the quality of meat-free sausages using k-carrageenan, konjac mannan and xanthan gum. Int. J. Food Sci. Technol. 2017, 52, 1269-1275. [CrossRef]

21. Estévez, M.; Ventanas, J.; Cava, R.; Puolanne, E. Characterisation of a traditional Finnish liver sausage and different types of Spanish liver pâtés: A comparative study. Meat Sci. 2005, 71, 657-669. [CrossRef]

22. Kurita, K. Controlled functionalization of the polysaccharide chitin. Prog. Polym. Sci. 2001, 26, 1921-1971. [CrossRef]

23. Hadidi, M.; Jafarzadeh, S.; Ibarz, A. Modified mung bean protein: Optimization of microwave-assisted phosphorylation and its functional and structural characterizations. LWT Food Sci. Technol. 2021, 151, 112119. [CrossRef]

24. de Oliveira Ferreira, N.S.; Rosset, M.; Lima, G.; Stuelp Campelo, P.M.; de Macedo, R.E.F. Effect of adding Brosimum gaudichaudii and Pyrostegia venusta hydroalcoholic extracts on the oxidative stability of beef burgers. LWT Food Sci. Technol. 2019, 108, 145-152. [CrossRef]

25. Minelli, G.; Fiego, D.P.L.; Macchioni, P.; Fava, P. Effect of different illumination sources on colour and oxidative stability of seasoned coppa di parma pgi. Ital. J. Food Sci. 2020, 32, 181-194. [CrossRef]

26. Turhan, S.; Sagir, I.; Sule Ustun, N. Utilization of hazelnut pellicle in low-fat beef burgers. Meat Sci. 2005, 71, 312-316. [CrossRef]

27. Jerónimo, E.; Alfaia, C.M.M.; Alves, S.P.; Dentinho, M.T.P.; Prates, J.A.M.; Vasta, V.; Santos-Silva, J.; Bessa, R.J.B. Effect of dietary grape seed extract and Cistus ladanifer L. in combination with vegetable oil supplementation on lamb meat quality. Meat Sci. 2012, 92, 841-847. [CrossRef]

28. Hadidi, M.; Pourya, I.A.; Zarei Jelyani, A.; Hasiri, Z.; Rouhafza, A.; Ibarz, A.; Baradaran Khaksar, F.; Tajbakhsh Tabrizi, S. Polysaccharides from pineapple core as a canning by-product: Extraction optimization, chemical structure, antioxidant and functional properties. Int. J. Biol. Macromol. 2020, 163, 2357-2364. [CrossRef] [PubMed]

29. Domínguez, R.; Pateiro, M.; Gagaoua, M.; Barba, F.J.; Zhang, W.; Lorenzo, J.M. A comprehensive review on lipid oxidation in meat and meat products. Antioxidants 2019, 8, 429. [CrossRef] [PubMed]

30. Lorenzo, J.M.; Pateiro, M. Influence of fat content on Physico-chemical and oxidative stability of foal liver pâté. Meat Sci. 2013, 95, 330-335. [CrossRef] [PubMed]

31. Lorenzo, J.M.; Temperán, S.; Bermúdez, R.; Purriños, L.; Franco, D. Effect of fat level on physicochemical and sensory properties of dry-cured duck sausages. Poult. Sci. 2011, 90, 1334-1339. [CrossRef]

32. Fonseca, S.; Gómez, M.; Domínguez, R.; Lorenzo, J.M. Physicochemical and sensory properties of Celta dry-ripened "salchichón" as affected by fat content. Grasas Aceites 2015, 66, e059. [CrossRef]

33. Lorenzo, J.M.; Franco, D. Fat effect on physicochemical, microbial and textural changes through the manufactured of dry-cured foal sausage Lipolysis, proteolysis and sensory properties. Meat Sci. 2012, 92, 704-714. [CrossRef] [PubMed]

34. Leite, A.; Rodrigues, S.; Pereira, E.; Paulos, K.; Oliveira, A.F.; Lorenzo, J.M.; Teixeira, A. Physicochemical properties, fatty acid profile and sensory characteristics of sheep and goat meat sausages manufactured with different pork fat levels. Meat Sci. 2015, 105, 114-120. [CrossRef] [PubMed]

35. McKenna, D.R.; Mies, P.D.; Baird, B.E.; Pfeiffer, K.D.; Ellebracht, J.W.; Savell, J.W. Biochemical and physical factors affecting discoloration characteristics of 19 bovine muscles. Meat Sci. 2005, 70, 665-682. [CrossRef] [PubMed]

36. Gharibzahedi, S.M.T.; Rostami, H.; Yousefi, S. Formulation Design and Physicochemical Stability Characterization of Nanoemulsions of Nettle (Urtica dioica) Essential Oil Using a Model-Based Methodology. J. Food Process. Preserv. 2015, 39, $2947-2958$. [CrossRef]

37. Jeyakumari, A.; George, N.i.n.a.n.; Joshy, C.G.; Parvathy, U.; Zynudheen, A.A.; Lalitha, K.V. Effect of chitosan on shelf life of restructured fish products from pangasius (pangasianodon hypophthalmus) surimi during chilled storage. J. Food Sci. Technol. 2016, 53, 2099-2107. [CrossRef] 